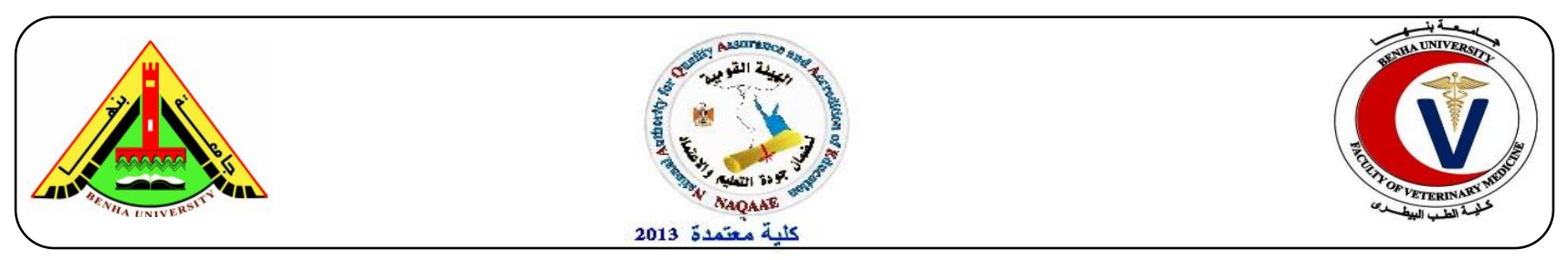

\title{
Convenience of rapid detection tests in suspecting prevalence of FMD virus in Egypt between 2016-2017.
}

Gabr, F. El-Bagoury ${ }^{1}$, Nashwa, M. Helmy ${ }^{2}$, Ayman, S. El-Habbaa ${ }^{1}$ and Rawan, A. ElHabashy $^{2}$

${ }^{1}$ Department of Virology, Faculty of Veterinary Medicine, Benha University.

${ }^{2}$ Animal Health Research Institute, Dokki, Cairo.

\section{A B S T R A C T}

Egypt is endemic for Foot and mouth disease (FMD) virus with continuous long-lasting outbreaks in different provinces causing significant losses in the animal livestock. This study was designed to show convenience of rapid detection tests in suspecting prevalence of FMD virus in Egypt during autumn and winter 2016 and spring and summer 2017. Samples collected from clinically suspected cattle and buffaloes at different governorates, were subjected to antigen detection ELISA and real time reverse transcription polymerase chain reaction (rRT-PCR). Although FMD virus serotype O is more prevalent during that period, serotypes A and SAT2 were also found in less prevalent cases. It was showed that from 2018 samples, $62(28.44 \%)$ and $72(33.02 \%)$ samples were positive for FMD virus (Serotypes A, O and SAT2) using antigen detection ELISA and rRT-PCR, respectively. Trials for virus isolation on BHK-21 from aseptically prepared 24 positive samples by antigendetection ELISA and rRT-PCR, revealed four isolates, three for serotype O samples and one SAT2. Finally, rRT-PCR was employed as it has a greater sensitivity over the conventional ELISA and virus isolation for the diagnosis of FMD virus suspected samples which are not detected by the ELISA or not produce a CPE in cell cultures with fast and quantitative assessment of the virus.

Key words: FMDV, ELISA, rRT-PCR, Virus isolation.

(http://www.bvmj.bu.edu.eg)

(BVMJ-33(2): 476-488, 2017)

\section{INTRODUCTION}

Foot and mouth disease (FMD) virus belongs to the genus Aphthovirus of the family Picornaviridae (Longjam et al., 2011). It cause a highly contagious disease affecting wide range of cloven hoofed animals including cattle, buffaloes, sheep, goats, pigs and camels and more than 70 wildlife species (Alexandersen et al., 2003; Jamal and Belsham, 2013). This devastating disease causes a huge global losses of livestock production, trade restrictions and large-scale epidemics (Chase-Topping et al., 2008).

FMD virus is a small non-enveloped virus with a pseudo $\mathrm{T}=3$ icosahedral capsid (30 nm diameter) made up of 60 copies each of four structural proteins VP1 (1D), VP2 (1B), VP3 (1C) and VP4 (1A). The capsid surrounds an 8.4-kilobase long, positivesense, single-stranded RNA genome (Belsham et al., 2011). The genome has a 
covalently bound $5^{\prime}$ end with small viral protein 3B (about $1300 \mathrm{nt}$ ) and a polyadenylated 3'end (about $90 \mathrm{nt}$ ) and in between present a large single open reading frame (ORF), about $7000 \mathrm{nt}$ (Carrillo et al.,2005). This ORF is organized into $\mathrm{L}$ region (located at $5^{\prime}$ end and codes for $\mathrm{L}^{\text {pro }}$ ), P1 region (encoding a precursor for capsid polypeptide, which can generate four mature capsid proteins VP4, VP2, VP3, and VP1 upon cleavage by viral protease), $\mathrm{P} 2$ region (encodes three viral proteins $2 \mathrm{~A}, 2 \mathrm{~B}$, and 2C) and $\mathrm{P} 3$ region (encodes four viral proteins $3 \mathrm{~A}$, $3 \mathrm{~B}, 3 \mathrm{C}^{\mathrm{pro}}$ and $3 \mathrm{D}^{\mathrm{pol}}$, in which, $3 \mathrm{C}$ is a viral protease and 3D an RNA-dependent RNA polymerase), (Klump et al., 1984). VP1 is the most immunogenic protein and it's nucleotide sequences have been used for genetic characterization of the viral strains because of their significance for antigenic heterogeneity, protective immunity, cell-virus attachment and entry, serotype specificity and forming the large part of the virus surface about $54 \%$ of the surface ((Chase-Topping et al., 2008 and Valdazo-González et al., 2012). FMD virus classified into seven genetically and serologically distinct types with indistinguishable clinical effects and no cross protection namely types $\mathrm{O}, \mathrm{A}, \mathrm{C}$, Southern African Territories (SAT) 1,2,3 and Asia 1 with many different distinct 'sub-types' due to the high mutation rate during the virus replication (Alexandersen et al., 2003).

The virus can enter the body by inhalation, ingestion or through skin abrasions and mucous membranes. All secretions and excretions (saliva, nasal and lachrymal fluid, milk, urine, semen, feces and expired breath) become infectious during FMD course while some contain significant virus titers before clinical signs appearance (OIE, 2014).

Egypt is endemic with 3 serotypes O, A and SAT2 (OIE, 2013). Failure of successful control of the disease in Egypt is mainly due to large population of susceptible animals, absence of restriction on animal movement, limited availability of vaccines and other socio-economic conditions.

ELISA and Virus isolation are the gold standard tests for diagnosis of FMD based on their suitability to detect the presence of FMDV antigen in tissue samples (Shaw et al., 2004). In recent years rRT-PCR has been applied because it can detect a small fragment of FMDV genomic RNA, virus in low concentration which are not detected by ELISA or live virus produce a CPE in cell cultures, with high sensitivity and in short time over the other conventional procedures (Reid et al., 2002). The present work aimed for studying suitability of diagnostic techniques in studying prevalence of FMD virus among suspected cattle and buffaloes in Egypt during autumn and winter 2016 and spring and summer 2017; respectively.

\section{Materials and methods}

\subsection{Virological Samples:}

A total number of 218 suspected samples collected either from anti-mortem or postmortem cases $(117,45,27$ and 29 samples

from tongue epithelium, vesicular fluid, myocardial tissue and pharyngeal swabs, respectively) were collected from cattle and buffaloes suspecting FMD from different governorates in Egypt at the period 2016/2017 (Table 1). These samples were labeled, transported in transport media $\mathrm{pH}$ 7.0-7.4 and processed according to OIE terrestrial manual (2009) and stored at $-80^{\circ} \mathrm{C}$ until used for rRT-PCR, ELISA and isolation.

\subsection{Antigen Detection ELISA:}

FMD virus antigen detection ELISA serotyping FMD virus O, A, SAT1 and SAT2. ISZLER: Brescia, Italy (IAH, Pirbright, UK) according to the 
instructions of manufacturer.

\subsection{Isolation of FMD Virus:}

Baby Hamster Kidney (BHK 21) cell line was used for primary isolation of FMD virus according to the technique described by (Macpherson and Stocher, 1962). obtained from virology department at Animal Health Research Institute (AHRI), ElDokki, Giza, Egypt and propagated using Minimum Essential Medium (MEM) with Hank's salts and 10\% sterile Fetal calf serum.

\subsection{Real Time reverse transcription -}

Polymerase Chain Reaction (rRT-PCR):

Viral RNA extraction was performed on suspected prepared samples using Thermo scientific Gene Jet RNA purification (cat no.00339196, USA) according to the instructions of manufacturer and was stored at $-80^{\circ} \mathrm{C}$ till use. qRT-PCR kit that is rehydrated and used according to instruction manual was used using a real-time PCR machine (Stratagene mx500sp, USA) with the thermal profile according to the manufacture instructions. The universal probe and primers were designed according to Callahan et al., (2002) as shown in table (2). Briefly $20 \mu \mathrm{l}$ q RT-PCR mix was prepared and mixed thoroughly by pipetting $(4 \mu \mathrm{l}$ Mix stable q RT- PCR 5x, $1 \mu$ l Primer/ Probe Specific, $10 \mu \mathrm{l}$ DNase/RNase free water and 5 $\mu l$ Template (either sample, positive or negative control) with thermal profile $42^{\circ} \mathrm{C}$ for $10 \mathrm{~min}$ (for reverse transcription), $95^{\circ} \mathrm{C}$ for $15 \mathrm{~min}$ (for activation), $95^{\circ} \mathrm{C}$ for $15 \mathrm{sec}$ (for denaturation) and $60^{\circ} \mathrm{C}$ for $60 \mathrm{~min}$ for 50 cycles (Hybridization, extension, data collection.).

\section{RESULTS}

3.1 Studying prevalence of FMD between cattle and buffaloes from different governorates using antigen detection serotyping ELISA and rRT-PCR:
Testing of samples from clinically suspected cattle and buffalo from different governorates in Egypt between 2016 - 2017 showed that 62 and 72 samples (out of 218 samples) were positive for FMD virus using antigen detection ELISA and rRT-PCR, respectively (tables 3 and 4).

Positive cases for FMD virus serotype $\mathrm{O}$ using antigen detection ELISA was distributed in Dakahlya (14), Banisweif (12), Behera (8), Menofia (7), Domiatte (4), Gharbia (2), Newvalley (one), Port-said (2), Menia (2), Fayoum (one), Assuit (one) and Sharquia (2). Positive cases for FMD virus serotype A was distributed in Domiatte (one), Cairo (one) and Fayoum (one). Positive cases for FMD virus serotype SAT2 was distributed in Dakahlya (one), Banisweif (one), and Alexandria (one).

Positive cases for FMD virus serotype O using Rrt-PCR was distributed in Dakahlya (12), Banisweif (12), Behera (11), Menofia (5), Domiatte (4), Gharbia (3), Newvalley (2), Port-said (4), Menia (2), Suez (2), Alexandria (one), Fayoum (one), and Luxur (one). Positive cases for FMD virus serotype A was distributed in Domiatte (one), Cairo (one) and Fayoum (one). Positive cases for FMD virus serotype SAT2 was distributed in Dakahlya (2), Banisweif (6), and Newvalley (one).

\subsection{Comparative detection of FMD virus} serotypes in suspected samples using antigen detection ELISA and rRT-PCR:

Detection of FMD virus in suspected samples showed that $62(28.44 \%)$ and 72 (33.02\%) samples (out of 218 samples) were positive for FMD virus using antigen detection ELISA and rRT-PCR, respectively (table 5 and figures 1, 2 and 3).

positive results were showed in 52 out of 117 (44.44\%) tongue epithelium samples and 5 out of $45(11.11 \%)$ vesicular fluid samples and in 5 out of 27 (18.51\%) 
myocardial tissue samples and in 0 out of 29 pharyngeal swab samples using antigen detection ELISA, while positive results were showed in 49 out of $117(41.88 \%)$ tongue epithelium samples and 4 out of $45(8.88 \%)$ vesicular fluid samples and in 7 out of 27 (25.92\%) myocardial tissue samples and in 12 out of 29 (41.37\%) pharyngeal swab samples using rRT-PCR.

\subsection{Trials for isolation of FMD virus on} BHK-21 cell line:

Twenty-four samples $(11,7,3,3$ from tongue epithelium, vesicular fluid, myocardial tissue and pharyngeal swabs) positive for FMD virus detection by ELISA and Real time PCR $(15,4,5$ for serotype O, A and SAT2, respectively) were inoculated onto confluent monolayer sheet of BHK-21 cell-culture then examined daily for 3 successive days for CPE.

Results revealed that only three FMD virus serotype $\mathrm{O}$ samples ( 2 from myocardial tissue and one from tongue epithelium samples) and one FMD virus serotype SAT2 (from tongue epithelium sample) were positive for isolation on BHK-21 cells and CPE occurred after $48 \mathrm{hrs}$ post inoculation at the third passage (table 6 and Fig. 4). The three FMD virus isolates on cell culture were harvested and tested using serotyping antigen detection ELISA and all give positive results.

Table (1). List of suspected samples collected from antimortem and postmortem cases for FMDV infection from different governorates.

$$
\begin{gathered}
\text { Number and species of } \\
\text { suspected animals }
\end{gathered}
$$

\begin{tabular}{|c|c|c|c|c|c|c|c|}
\hline Governorate & Cattle & Buffalo & Total & $\begin{array}{l}\text { Tongue } \\
\text { epithelium }\end{array}$ & $\begin{array}{l}\text { Vesicular } \\
\text { fluid }\end{array}$ & $\begin{array}{l}\text { Myocardial } \\
\text { tissue }\end{array}$ & $\begin{array}{c}\text { Phar } \\
\text { ynge } \\
\text { al } \\
\text { swab }\end{array}$ \\
\hline Dakahlya & 16 & 14 & 30 & 13 & 5 & 7 & 5 \\
\hline Banisweif & 23 & 5 & 28 & 24 & 2 & 1 & 1 \\
\hline Behera & 11 & 8 & 19 & 9 & 6 & 1 & 3 \\
\hline Menofia & 10 & 6 & 16 & 9 & 3 & 2 & 2 \\
\hline Domiatte & 8 & 5 & 13 & 9 & 2 & 1 & 1 \\
\hline Gharbia & 8 & 3 & 11 & 7 & 2 & 1 & 1 \\
\hline Newvalley & 7 & 3 & 10 & 3 & 4 & 2 & 1 \\
\hline Port-said & 9 & 3 & 12 & 5 & 2 & 1 & 4 \\
\hline Menia & 6 & 3 & 9 & 4 & 3 & 1 & 1 \\
\hline Suez & 6 & 3 & 9 & 3 & 2 & 3 & 1 \\
\hline Cairo & 5 & 3 & 8 & 4 & 2 & 1 & 1 \\
\hline Alexandria & 5 & 4 & 9 & 5 & 2 & 1 & 1 \\
\hline Fayoum & 6 & 5 & 11 & 6 & 2 & 1 & 2 \\
\hline Matrouh & 4 & 3 & 7 & 3 & 2 & 1 & 1 \\
\hline Luxur & 5 & 3 & 8 & 3 & 2 & 1 & 2 \\
\hline Assuit & 5 & 3 & 8 & 4 & 2 & 1 & 1 \\
\hline Sharquia & 6 & 4 & 10 & 6 & 2 & 1 & 1 \\
\hline Total & 140 & 78 & 218 & 117 & 45 & 27 & 29 \\
\hline
\end{tabular}

Number and types of suspected samples 
Table (2). List of suspected samples collected from antimortem and postmortem cases for FMDV infection from different governorates.

\begin{tabular}{cllc}
\hline Type & \multicolumn{1}{c}{ Sequence } & $\begin{array}{c}\text { Target } \\
\text { gene }\end{array}$ & Reference \\
\hline Forward Primer & 5'-ACTGGGTTTTACAAACCTGTGA-3' & 3D & Callahan et al., 2002 \\
Reverse Primer & 5'-GCGAGTCCTGCCACGGA-3' & & \\
TaqMan Probe & 5'-FAM-TCCTTTGCACGCCGTGGGAC-TAMRA-3' & & \\
\hline O(F) & 5''CAACACACGGACGTCGCG-3' & & Reid \\
O (R) & 5'-GTTGGGTTGGTKGTGTTGTC-3' & et al., 2014 \\
O Probe & 5'-FAM-GAGTTGGACCTGATGCAGACCC-BHQ1 & & \\
A(F) & 5'ACGACCATCCACGAGCTYC3' & \\
A(R) & 5'RCAGAGGCCTGGGACAGTAG3' & \\
A Probe & 5'-FAM-CGTGCGCATGAAACGTGCCG TAMRA-3' & & \\
Sat2(F) & 5'TGA AGA GGG CTG AGC TGTACT G3' & \\
Sat2(R) & 5'CTC AAC GTC TCC TGCCAG TTT3' & \\
Sat2 probe & 5'-FAM-ACA GAT TCG ACG CGC CCA TCG & \\
\hline
\end{tabular}


Table (3): Detection of FMD virus in suspected animals from different governorates using

\begin{tabular}{|c|c|c|c|c|c|}
\hline \multirow{3}{*}{ Governorate } & \multirow{2}{*}{\multicolumn{2}{|c|}{ Suspected animals }} & \multicolumn{3}{|c|}{ Serotypes of FMDV detected } \\
\hline & & & \multirow{2}{*}{$\mathrm{O}$} & \multirow{2}{*}{ A } & \multirow{2}{*}{ SAT2 } \\
\hline & Examined & Positive & & & \\
\hline Dakahlya & 30 & 15 & 14 & 0 & 1 \\
\hline Banisweif & 28 & 13 & 12 & 0 & 1 \\
\hline Behera & 19 & 8 & 8 & 0 & 0 \\
\hline Menofia & 16 & 7 & 7 & 0 & 0 \\
\hline Domiatte & 13 & 5 & 4 & 1 & 0 \\
\hline Gharbia & 11 & 2 & 2 & 0 & 0 \\
\hline Newvalley & 10 & 1 & 1 & 0 & 0 \\
\hline Port-said & 12 & 2 & 2 & 0 & 0 \\
\hline Menia & 9 & 2 & 2 & 0 & 0 \\
\hline Suez & 9 & 0 & 0 & 0 & 0 \\
\hline Cairo & 8 & 1 & 0 & 1 & 0 \\
\hline Alexandria & 9 & 1 & 0 & 0 & 1 \\
\hline Fayoum & 11 & 2 & 1 & 1 & 0 \\
\hline Matrouh & 7 & 0 & 0 & 0 & 0 \\
\hline Luxur & 8 & 0 & 0 & 0 & 0 \\
\hline Assuit & 8 & 1 & 1 & 0 & 0 \\
\hline Sharquia & 10 & 2 & 2 & 0 & 0 \\
\hline Total & 218 & 62 & 56 & 3 & 3 \\
\hline
\end{tabular}

antigen detection ELISA. 
Table (4): Detection of FMD virus in suspected animals from different governorates using rRT-PCR.

\begin{tabular}{|c|c|c|c|c|c|}
\hline \multirow{2}{*}{ Governorate } & \multicolumn{2}{|c|}{ Suspected animals } & \multicolumn{3}{|c|}{ Serotypes of FMDV detected } \\
\hline & Examined & Positive & $\mathrm{O}$ & A & SAT2 \\
\hline Dakahlya & 30 & 14 & 12 & 0 & 2 \\
\hline Banisweif & 28 & 18 & 12 & 0 & 6 \\
\hline Behera & 19 & 11 & 11 & 0 & 0 \\
\hline Menofia & 16 & 5 & 5 & 0 & 0 \\
\hline Domiatte & 13 & 5 & 4 & 1 & 0 \\
\hline Gharbia & 11 & 3 & 3 & 0 & 0 \\
\hline Newvalley & 10 & 3 & 2 & 0 & 1 \\
\hline Port-said & 12 & 4 & 4 & 0 & 0 \\
\hline Menia & 9 & 2 & 2 & 0 & 0 \\
\hline Suez & 9 & 2 & 2 & 0 & 0 \\
\hline Cairo & 8 & 1 & 0 & 1 & 0 \\
\hline Alexandria & 9 & 1 & 1 & 0 & 0 \\
\hline Fayoum & 11 & 2 & 1 & 1 & 0 \\
\hline Matrouh & 7 & 0 & 0 & 0 & 0 \\
\hline Luxur & 8 & 1 & 1 & 0 & 0 \\
\hline Assuit & 8 & 0 & 0 & 0 & 0 \\
\hline Sharquia & 10 & 0 & 0 & 0 & 0 \\
\hline Total & 218 & 72 & 60 & 3 & 9 \\
\hline
\end{tabular}


Table (5): Detection of FMD virus in suspected samples using antigen detection ELISA and rRT-PCR.

\begin{tabular}{|c|c|c|c|c|c|c|c|c|c|}
\hline \multirow{3}{*}{$\begin{array}{c}\text { Type of } \\
\text { suspected } \\
\text { Sample }\end{array}$} & \multirow{3}{*}{$\begin{array}{c}\text { Total } \\
\text { samples }\end{array}$} & \multicolumn{2}{|c|}{ Positive samples } & \multicolumn{6}{|c|}{ Samples positive for serotyping of FMD virus } \\
\hline & & \multirow[b]{2}{*}{ ELISA } & \multirow[b]{2}{*}{ rRT-PCR } & \multicolumn{2}{|c|}{$\mathrm{O}$} & \multicolumn{2}{|c|}{ A } & \multicolumn{2}{|c|}{ SAT2 } \\
\hline & & & & ELISA & $\begin{array}{l}\text { rRT- } \\
\text { PCR }\end{array}$ & $\begin{array}{l}\text { ELI } \\
\text { SA }\end{array}$ & $\begin{array}{l}\text { rRT- } \\
\text { PCR }\end{array}$ & ELISA & rRT-PCR \\
\hline $\begin{array}{c}\text { Tongue } \\
\text { Epithelium }\end{array}$ & 117 & $\begin{array}{c}52 \\
(44.44 \%)\end{array}$ & $\begin{array}{c}49 \\
(41.88 \%)\end{array}$ & 46 & 40 & 3 & 3 & 3 & 6 \\
\hline $\begin{array}{c}\text { Vesicular } \\
\text { Fluid }\end{array}$ & 45 & $\begin{array}{c}5 \\
(11.11 \%)\end{array}$ & $\begin{array}{c}4 \\
(8.88 \%)\end{array}$ & 5 & 2 & 0 & 0 & 0 & 2 \\
\hline $\begin{array}{l}\text { Myocardial } \\
\text { tissue }\end{array}$ & 27 & $\begin{array}{c}5 \\
(18.51 \%)\end{array}$ & $\begin{array}{c}7 \\
(25.92 \%)\end{array}$ & 5 & 7 & 0 & 0 & 0 & 0 \\
\hline Pharyngeal swab & 29 & $\begin{array}{c}0 \\
(0 \%)\end{array}$ & $\begin{array}{c}12 \\
(41.37 \%)\end{array}$ & 0 & 11 & 0 & 0 & 0 & 1 \\
\hline Total & 218 & $\begin{array}{c}62 \\
(28.44 \%)\end{array}$ & $\begin{array}{c}72 \\
(33.02 \%)\end{array}$ & 56 & 60 & 3 & 3 & 3 & 9 \\
\hline
\end{tabular}

Table (6): List of samples positive for FMDV isolation on BHK cell line.

\begin{tabular}{ccc} 
Type of & \multicolumn{2}{c}{$\begin{array}{c}\text { Samples subjected for isolation on } \\
\text { BHK cell line }\end{array}$} \\
\cline { 2 - 3 } Suspected sample & Examined & Positive \\
\hline Tongue Epithelium & 11 & 2 \\
Vesicular fluid & 7 & 0 \\
Myocardial tissue & 3 & 2 \\
Pharyngeal swab & 3 & 0 \\
Total & 24 & 4 \\
\hline
\end{tabular}




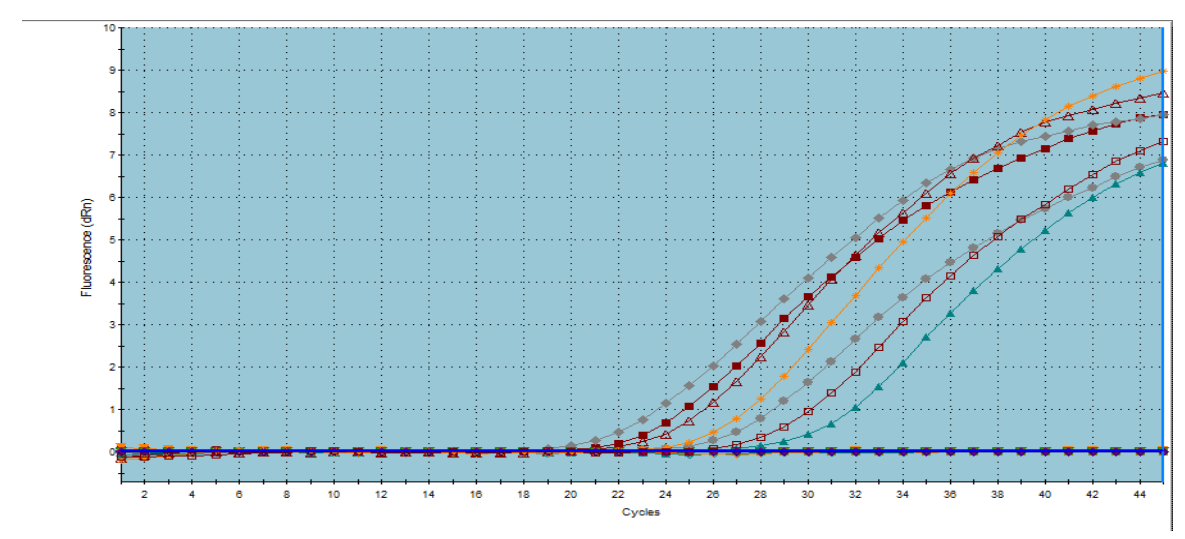

Fig. (1): Showing Multicomponent curve of serotype SAT2 where 9 tested samples were positive for SAT2 serotype.

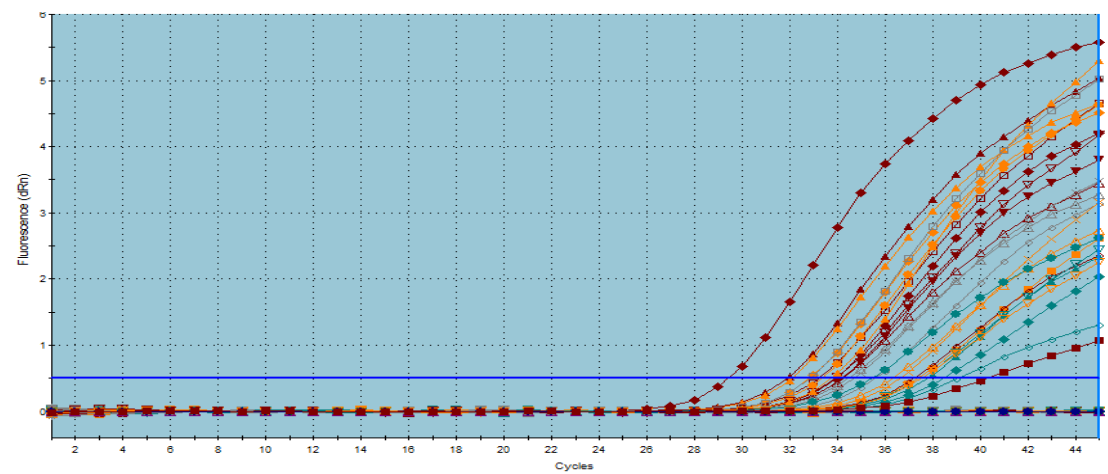

Fig. (2): Showing Multicomponent curve of serotype O positive samples serotype.

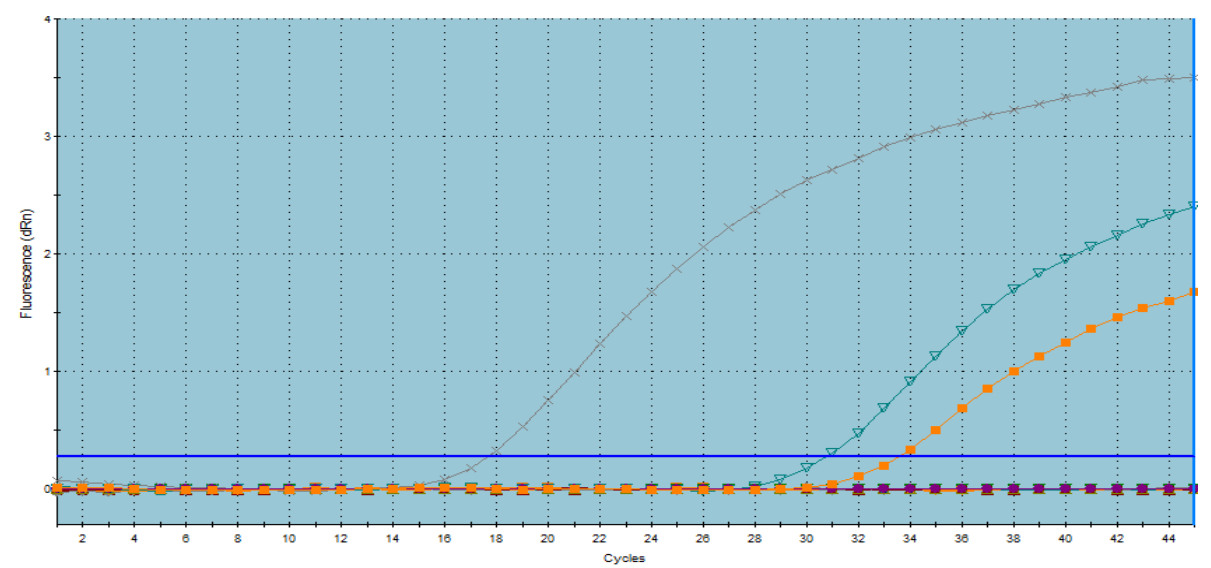

Fig. (3): Showing Multicomponent curve of serotype A where 3 tested samples were positive for A serotype. 

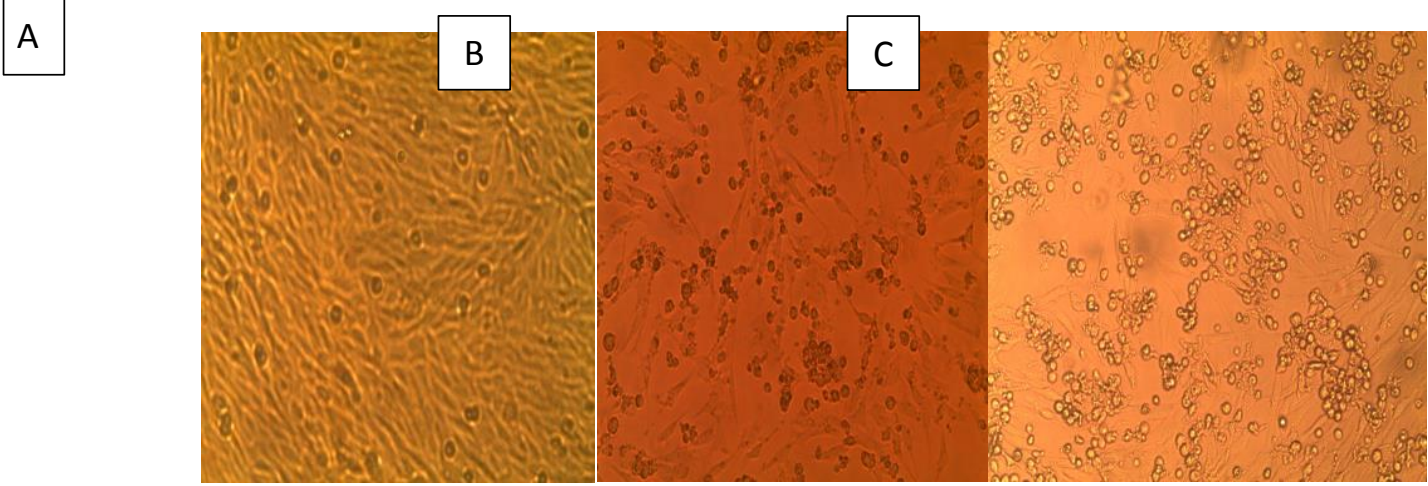

Fig. (4): Characteristic CPE of FMDV isolates on BHK 21 cell line in the form of rounding, granulation and cell detachment (A) Cell Control, (B) CPE of FMDV in BHK-21 cell culture 24 hours post infection, (C) CPE of FMDV in BHK-21 cell culture 48 hours post infection

\section{DISCUSSION}

Foot and mouth disease is a highly contagious viral disease affecting cattle, buffaloes, sheep, goats and camels (Alexanderson et al., 2003; Jamal and Belsham, 2013). it is caused by 7 immunologically distinct serotypes, O, A, C, Asia 1, South African Territories (SAT) 1, SAT 2, and SAT 3 belong to the species FMD virus (genus

Aphthovirus, family Picornaviridae), where Several of these serotypes circulate in the Middle East (Knowles and Samuel, 2003).

Egypt is endemic with 3 serotypes $\mathrm{O}$, A and SAT2 of FMD virus due to failure of the disease control. Early detection and serotyping of FMD virus in suspected samples is critical for appropriate and effective control of the disease (OIE, 2013).

For diagnosis of FMD virus. a range of sample types including epithelium, vesicular fluid and esophageal pharyngeal fluids may be examined by virus isolation, RT-PCR and ELISA (OIE, 2008).

The main objective of the present work is studying convenience of rapid detection tests in suspecting prevalence of FMD virus in Egypt during autumn and winter 2016 and spring and summer 2017; respectively through comparative detection and isolation of FMD virus from suspected samples (epithelial tissue, vesicular fluid, myocardial tissue and oral pharyngeal swabs) collected from cattle and buffaloes from different governorates in Egypt.

Samples were subjected to antigen detection ELISA and rRT-PCR (tables 3 and 4). Although FMD virus serotype $O$ is more prevalent during that period, serotypes $\mathrm{A}$ and SAT2 were also found in less prevalent cases. Positive cases for FMD virus serotype $O$ using antigen detection ELISA and RT-PCR was distributed in Sharquia, Gharbia, Menofia, Behera, Dakahlya, Alexandria, Domiatte, Banisweif, Fayoum, Menia, Assuit, Luxur, Newvalley, Port-said and Suez. Positive cases for FMD virus serotype A was distributed in Domiatte, Cairo and Fayoum, while positive cases for FMD virus serotype SAT2 was distributed in Dakahlya, Alexandria, Banisweif, and New valley. These findings agreed with the results of previous Egyptian studies showed that three FMDV serotypes O, A, SAT2 were responsible for 2011-2012 outbreaks (predominant serotype SAT2) (Salam et al., 2014), 2012-2013 outbreaks (predominant serotype O) (Rady et al.,2014), 2013-2014 
outbreaks (high prevalence to serotype O) (Diab et al., 2015) and 2016 outbreaks (high prevalence to serotypes A and O) (Soltan et al., 2017).

It was showed that 62 and 72 samples (out of 218 samples) were positive for FMD virus using antigen detection ELISA and rRTPCR, respectively (tables 3 and 4). Samples were initially screened using antigen detection ELISA as considered the preferred procedure for the detection and serotyping of FMD virus antigen (Hamblin et al., 1984; Roeder and Le Blanc Smith, 1987; Ferris and Dawson, 1988). It was found that samples were positive for FMD virus in a percentage of $28.44 \%$ with the three serotypes O, A, SAT2 and this is in agreement with (Longjam et al., 2011) that demonstrate that ELISA could detect FMD virus successfully. Tongue epithelium from the vesicular lesion is the sample of choice for FMDV detection as high concentrations of virus are associated with un ruptured and recently ruptured vesicles then pharyngeal swabs (Reid et al., 2001).

Detection of FMD virus in suspected samples was done by the universal primers and probes that were previously published by callahan et al., (2002) showed positive results in 72 out of 218 samples with a percentage of $33.02 \%$ (Table 3) this is in agreement with (Longjam et al., 2011) that demonstrate that Real Time-PCR could detect FMD virus in $(65.47 \%)$ of samples successfully and Shaw et al., (2004) who demonstrate that Real TimePCR could detect FMDV in (79.3\%) with additional (18\%) not detected by ELISA or Virus isolation that ensure this assay sensitivity over the other conventional assays.

Trails for isolation on BHK-21 cell line from 24 positive samples (by ELISA and Real time PCR) for three serial passages that were examined for CPE, surprisingly revealed only three positive FMDV serotype $\mathrm{O}$ samples and one positive FMDV serotype
SAT2 and this result wasn't predicted as according to Paixão et al. (2008) viral isolation from vesicular fluid and oral epithelium on BHK-21 is the most reliable diagnostic method. Negative results may be due to temperatures and $\mathrm{pH}$ changes which lead to a reduction in FMDV infectivity (Shaw et al., 2004).

As Virus isolation depend on the presence of infectious virus in sample while the ELISA can detect both infectious and noninfectious FMD viral antigen but in sufficient concentration (1-2 ng/ml), (Shaw et al., 2004, Reid et al., 2001). Real Time RT-PCR may have the greater sensitivity over ELISA and virus isolation (Reid et al., 2002). Further antigenic and genetic characterization for the isolated virus serotypes in comparison to other local and vaccinal strains were needed to study the probability of virus evolution. Finally, it is concluded that rapid detection, identification and serotyping of FMDV is critical for appropriate vaccine selection and effective control of the disease.

\section{REFERENCES}

Alexandersen, S.; Zhang, Z.; Donaldson, A.I.; Garland, A.J. 2003. The pathogenesis and diagnosis of foot-and-mouth disease. Journal of comparative pathology, 129, 1-36.

Belsham, G.J.; Jamal, S.M.; Tjørnehøj, K.; Bøtner, A. 2011. Rescue foot-andmouth disease viruses that are pathogenic for cattle from preserved viral RNA samples. PloS one, Volume 6, Issue 1, https://doi.org/10.1371/journal.pone.00 14621.

Callahan, J.D, Brown, F., Csorio, F.A, Sur, J.H., Kramer, E., Long, G.W, Lubroth, J, Ellis, S.J, Shoulars, K.S., Gaffney, K.L., Rock, D.L., Nelson, W.M. 2002. Use of a portable real-time reverse 
transcriptase-polymerase chain reaction assay for rapid detection of foot-andmouth disease virus. J. Am. Vet. Med. Assoc. 220: 1636-1642.

Carrillo, C.; Tulman, E.R.; Delhon, G.; Lu, Z.; Carreno, A.; Vagnozzi, A.; Kutish, G.F.; Rock, D.L. 2005. Comparative Genomics of Foot-and-Mouth Disease Virus. Journal of Virology, Vol. 79, No. 10 p. 6487-6504.

Chase-Topping, M.E.; Handel, I.; Bankowski, B.M.; Juleff, N.D.; Gibson, D.; Cottam, E.M.; Wadsworth, J.; Shaw, A.E.; Rowlands, R.J.; Goatley, L.; Maan, S.; Maan, N.S.; Mertens, P.P.; Ebert, K.; Li, Y.; Ryan, E.D.; Juleff, N.; Ferris, N.P.; Wilesmith, J.W.; Haydon, D.T.; King, D.P.; Paton, D.J.; Knowles, N.J. 2008. Transmission pathways of footand-mouth disease virus in the United Kingdom in 2007. PLoS. Pathog., 4:e1000050.

Diab, E.; Bazid, A.; Fayed, A.; Magdy M.; El-Sayed, M.M. 2015. Some Epidemiological Studies on Foot and Mouth Disease (FMD) in Cattle and Buffalo in Egypt. M.S.C. Thesis, Fac. Vet. Medicine, Cairo Univ., Egypt.

Ferris, N.P.; Dawson, M. 1988. Routine application of enzyme-linked immune sorbent assay in comparison with complement fixation for the diagnosis of foot-and-mouth and swine vesicular diseases. Veterinary Microbiology, 16, $201-209$.

Hamblin, C.; Armstrong, R.M.; Hedger, R.S. 1984. A rapid enzyme-linked immunosorbent assay for the detection of foot-and-mouth disease virus in epithelial tissues. Vet. Microbiol. 9, 435-443.
Jamal, S.M.; Belsham, G.J. 2013. Foot-andmouth disease: past, present and future. Veterinary research, 44: 116.

Klump, W., Marquardt, O. and Hofschneider, P.H. (1984): Biologically active protease of foot and mouth disease virus is expressed from cloned viral cDNA in Escherichia coli. Proc. Natl. Acad. Sci. USA; 81:3351-5.

Knowles, N.J.; Samuel, A.R. 2003. Molecular epidemiology of foot and mouth disease virus. Virus Res., 91: 6.

Longjam, N.; Deb, R.; Sarmah, A.K.; Tayo, T.; Awachat, V.B.; Saxena, V.K. 2011. A Brief Review on Diagnosis of Footand-Mouth Disease of Livestock: Conventional to Molecular Tools. Veterinary Medicine International, Volume 2011, 1-17.

Macpherson, I.; Stocker, M.G.P. 1962. Polyoma transformation of hamster cell clones and investigation of genetic factors affecting cell competence. Virology16,147-151.

OIE, 2008. Chapter 2.1.5. Foot and Mouth Disease. Pp. 1-29. www.oie.int.

OIE, 2013. Molecular epidemiology reports. Reference Laboratory Reports,30:5-10.

OIE, 2014. "List of FMD free Member Countries". OIE. Retrieved 2014-08-04.

Paixão, T.; Neta, A.; Paiva, N.; Reis, J.; Barbosa, M.; Serra, C.; Silva, R.; Martin, B.; Clark, N.; Adams, L.; Santos, R. 2008. Diagnosis of foot- and mouth disease by real time reverse transcription polymerase chain reaction under field conditions in Brazil. Vet. Res., 4:53.

Rady, A.A.; Khalil, S.A.; Helmy, A.T. 2014. Molecular Epidemiology of FMDV in Northern Egypt (2012-2014). 
Alexandria Journal of Veterinary Sciences 2014, 41: 120-130.

Reid, S.M.; Ferris, N.P.; Hutchings, G.H.; Zhang, Z.; Belsham, G.J.; Alexandersen, S. 2001. Diagnosis of foot-and-mouth disease by real-time fluorogenic PCR assay. Veterinary Record, 149,621 - 623 .

Reid, S.; Ferris, N.; Hutchings, G.; Zhang, Z.; Belsham, G.; Alexandersen, S. 2002. Detection of all seven serotypes of footand-mouth disease virus by real-time, fluorogenic reverse transcription polymerase chain reaction assay. Journal of Virological Methods,105,67 -80 .

Roeder, P.L.; Le Blanc Smith, P.M. 1987. Detection and typing of foot-and-mouth disease virus by enzyme-linked immunosorbent assay: a sensitive, rapid and reliable technique for primary diagnosis.Research inVeterinary Science,43,225 - 232.

Salam, H.M.; ELshemey, T.M.; Mahmoud, A.A. 2014. Isolation, sequencing and phylogenetic analysis of FMDV strains during 2011-2012 outbreaks
International journal of agriculture innovations and research volume 3 issue4 2319-1473.

Shaw, A.E.; Reid, S.M.; King, D.P.; Hutchings, G.H.; Ferris, N.P. 2004. Enhanced laboratory diagnosis of foot and mouth disease by real-time polymerase chain reaction. Revue scientifique et technique-Office international des epizooties, 23, 10031009.

Soltan, M.A.; Negmaldin, A.H.; El-Diasty, M.M.; Shimaa M.G. Mansour; Maha A. Elbadry; Rebecca P. Wilkes 2017. Molecular characterization of circulating Foot and mouth disease virus (FMDV) serotype O topotype EA3 and serotype A (African topotype) genotype IV in Egypt, 2016. Veterinary Microbiology Volume 208, Pages 8993.

Valdazo-González, B.; Knowles, N.J.; Hammond, J.; King, D.P. 2012. Genome sequences of SAT 2 foot-andmouth disease viruses from Egypt and Palestinian Autonomous Territories (Gaza Strip).J. Virol., 86,8901-8902. 